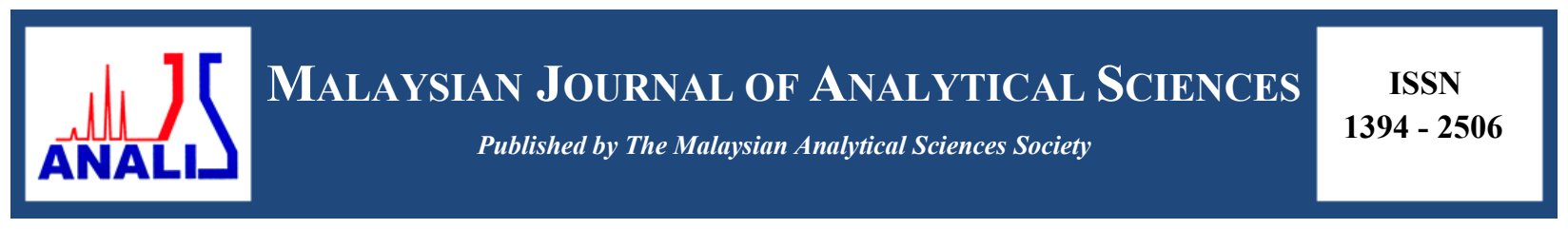

\title{
MACRO, MICRO, AND NON-ESSENTIAL ELEMENTS IN DIFFERENT PARTS OF Rhizophora apiculata
}

\section{(Makro, Mikro dan Elemen Tidak Perlu di dalam Pelbagai Bahagian Rhizophora apiculata)}

\author{
Fathullah Abdullah $^{1}$, Hasrizal Shaari ${ }^{1,2}$, Behara Satyanarayana ${ }^{2}$, Wan Mohd Afiq Wan Mohd Khalik ${ }^{1}$, \\ Mohd. Zaidi Mohd. Jaafar ${ }^{1}$ \\ ${ }^{1}$ School of Marine and Environmental Science \\ ${ }^{2}$ Institute of Oceanography and Environment \\ Universiti Malaysia Terengganu, 21030 Kuala Nerus, Terengganu,Malaysia \\ *Correspondingauthor: riz@umt.edu.my
}

Received: 26 August 2017; Accepted: 1 July 2018

\begin{abstract}
A total of 50 samples of different parts (roots, stem disks, barks, trunks, twigs, and leaves) from five individuals of 20 -year-old Rhizophora apiculata were sampled at Matang Mangrove Forest, Kuala Sepetang, Perak. The aims of this study were to determine the concentration of selected macroelements ( $\mathrm{K}, \mathrm{Mg}, \mathrm{Na}$, and $\mathrm{Ca}$ ), microelements ( $\mathrm{Al}, \mathrm{Fe}, \mathrm{Zn}, \mathrm{Mn}$ and $\mathrm{Cu}$ ) and nonessential elements $(\mathrm{Pb}$ and $\mathrm{Cd})$ in different parts of $R$. apiculata. The elemental analysis was conducted by using inductively coupled plasma-optical emission spectrometer (ICP-OES). The mean value of the studied elements was recorded in the decreasing order of $\mathrm{Ca}>\mathrm{Na}>\mathrm{K}>\mathrm{Mg}>\mathrm{Mn}>\mathrm{Al}>\mathrm{Fe}>\mathrm{Zn}>\mathrm{Cu}>\mathrm{Pb}>\mathrm{Cd}$. The highest value of Ca compared to other elements in the major parts of $R$. apiculata is closely related to the role of this element in the cell wall formation. The variable concentration of elements in the different parts of $R$. apiculata is attributed to the absorption mechanism of the trees. High values of some macroelements than microelements suggest that a macroelement is more significant for the growth of $R$. apiculata. The lower mean values of $\mathrm{Pb}$ and $\mathrm{Cd}$ than other elements suggest that non-essential elements are not significantly involved in the major process of this mangrove species. This study is crucial in providing a preliminary data of the different types of elements in the different parts of the R. apiculata species, and its importance for the future development of the charcoal industry in Kuala Sepetang, Perak.
\end{abstract}

Keywords: Mangrove forest, Rhizophora apiculata, macroelement, microelement, non-essential element

\section{Abstrak}

Sebanyak 50 sampel terdiri daripada pelbagai bahagian (akar, batang pokok, kulit, dahan, ranting dan daun) daripada 5 batang pokok spesis Rhizophora apiculata berusia 20 tahun telah di ambil di Hutan Simpan Matang. Kuala Sepetang, Perak. Tujuan kajian ini adalah untuk mencari nilai kepekatan elemen yang terpilih daripada makroelemen ( $\mathrm{K}, \mathrm{Mg}$, $\mathrm{Na}$ dan $\mathrm{Ca})$, mikroelemen $(\mathrm{Al}, \mathrm{Fe}, \mathrm{Zn}, \mathrm{Mn}$ and $\mathrm{Cu}$ ) and elemen tidak perlu ( $\mathrm{Pb}$ dan $\mathrm{Cd}$ ) yang terdapat dalam pelbagai bahagian pokok R. apiculata. Kaedah mendapatkan elemen adalah dengan menggunakan spektrometer pancaran optikal- gandingan aruhan plasma (ICP-OES). Purata jumlah elemen dalam kajian ini dicatat dalam kedudukan menurun daripada $\mathrm{Ca}>\mathrm{Na}>\mathrm{K}>\mathrm{Mg}>\mathrm{Mn}>\mathrm{Al}>\mathrm{Fe}>\mathrm{Zn}>\mathrm{Cu}>\mathrm{Pb}$ $>\mathrm{Cd}$. Elemen $\mathrm{Ca}$ adalah tertinggi jika dibandingkan dengan elemen yang lain adalah disebabkan pokok Rhizophora apiculata memerlukan elemen ini untuk pembentukkan sel-sel dinding. Jumlah elemen yang pelbagai adalah disebabkan daripada cara mekanisma penyerapan pokok tersebut. Makroelemen tinggi dari mikroelemen adalah disebabkan makroelemen memerlukan sejumlah besar untuk proses tumbesaran pokok. Elemen $\mathrm{Pb}$ dan $\mathrm{Cd}$ dicatat rendah dibandingkan element lain disebabkan elemen ini tidak terlibat secara terus dalam proses utama tumbesaran pokok ini. Kajian ini dikaji adalah untuk rujukan bagi spesis Rhizophora apiculata dan ini adalah penting bagi pembuatan industri arang kayu di Kuala Sepetang, Perak.

Kata kunci: Hutan bakau, Rhizophora apiculata, makroelemen, mikroelemen, elemen tak perlu 


\section{Introduction}

Mangrove is a dominant coastal vegetation community in tropical Asia where Malaysia-Indonesia is the centre of distribution [1]. There are over 15 million hectares of mangrove forest in over 121 countries [2, 3]. River deltas, lagoons, and estuaries are mostly preferred for the growth of mangrove plants due the special adaptation in saline environment. These areas are well adapted for the life in the tidal habitat [4]. Previous reports revealed that mangrove area is one of the most productive environments [5, 6]. The distribution of mangrove forest in Peninsular Malaysia is relatively dense in the west than the east coast. For example, Kuala Sepetang in Perak is known with its diversity of mangrove species and is very clear in forest zonation.

High density of mangrove trees helps in trapping sediments carried by rivers. This results in high sedimentation rate in mangrove forests and provides a good condition for elemental deposition with sediment deposits. The deposited elements will be absorbed by roots and distributed to the different parts of the mangrove tree. Consequently, a mangrove tree can be a suitable indicator of metal pollution because it has a high tolerance to metal accumulation and acts as long-term sinks for most metals [7, 8].

Studies on element contents in different parts of a mangrove tree in tropical environments, including Malaysia, are not well documented. To the best of our knowledge, there is only two published works in Malaysia, reported by Kamaruzaman and Ong [9] in Setiu Wetlands, Terengganu and Kamaruzzaman et al [10] in Balok, Pahang. However, their study is limited on some elements without focusing on the elemental content in the different parts of a mangrove tree. Thus, in this study, the concentration of macroelements $(\mathrm{K}, \mathrm{Mg}, \mathrm{Na}$, and $\mathrm{Ca})$, microelements $(\mathrm{Al}$, $\mathrm{Fe}, \mathrm{Zn}, \mathrm{Mn}$, and $\mathrm{Cu}$ ), and non-essential elements $(\mathrm{Pb}$ and $\mathrm{Cd})$ in roots, stem disks, barks, branches, twigs, and leaves of Rhizophora apiculata in the mangrove reserve forest of Kuala Sepetang was investigated.

\section{Materials and Methods}

\section{Description of study area}

Kuala Sepetang Reserved Forest, Perak is located near Kuala Larut and the intersection between Sangga Besar River and Sepetang River. The Forestry Department of Perak has implemented a systematic plantation and harvesting of mangrove tree from the species of Rhizophora apiculata and Rhizophora mucronata for charcoal industry. They divided this large forest area into several compartments in order to manage it appropriately. The study area is located far from human settlement and there is no development occurred within the gazetted area. There is a small river called Terusan Tima that is located near to the sampling location. The coordinate of each sampling location is tabulated in Table 1.

Table 1. The coordinate of each sampling locations

\begin{tabular}{lcc}
\hline Sampling Point & Latitude (N) & Longitude (E) \\
\hline 1 & $04^{\circ} 50^{\prime} 38.076^{\prime \prime}$ & $100^{\circ} 37^{\prime} 11.532^{\prime \prime}$ \\
2 & $0^{\circ} 50^{\prime} 38.760^{\prime \prime}$ & $100^{\circ} 37^{\prime} 10.704^{\prime \prime}$ \\
3 & $0^{\circ} 50^{\prime} 38.760^{\prime \prime}$ & $100^{\circ} 37^{\prime} 10.596^{\prime \prime}$ \\
4 & $0^{\circ} 50^{\prime} 38.184^{\prime \prime}$ & $100^{\circ} 37^{\prime} 09.444^{\prime \prime}$ \\
5 & $04^{\circ} 50^{\prime} 37.464^{\prime \prime}$ & $100^{\circ} 37^{\prime} 10.020^{\prime \prime}$ \\
\hline
\end{tabular}

\section{Sample collection and preparation}

Five individuals of 20-year-old $R$. apiculata were sampled at the Kuala Sepetang Reserve Forest in March 2016 with the help of logging contractors under the Forestry Department of Perak. The tree samples were cut and separated into six different parts of roots, stem disks, barks, branches, twigs, and leaves. The stem disk was divided into three segments: bottom, middle, and top. Each component of the trees was wrapped and stored in an icebox in order to avoid contamination from the environment. The samples were brought back to the laboratory and cleaned with distilled water. The samples were dried in oven at $65^{\circ} \mathrm{C}$ for 72 hours. The dried samples were polished with 
sandpaper to remove any metal effects during the cutting process. The samples were subjected to ultrasonic treatment and cleaned with distilled water in order to remove any impurity particles. Again, the samples were dried in oven at $65^{\circ} \mathrm{C}$ for 72 hours. The dried samples were burned combustion in a furnace at $500{ }^{\circ} \mathrm{C}$ for 10 hours. The ashes of burned samples were stored in a glass container prior to further analysis.

\section{Sample digestion and analysis}

The analysis followed the proposed procedure by $\mathrm{Wu}$ et al. [11] with some modifications on the digesting time. An approximately $0.05 \mathrm{~g}$ of homogenised ashes sample was digested in $1.5 \mathrm{ml}$ of nitric acid by using a microwave digestion oven (Advanced Microwave Digestion System, ETHOS One). The analysis of the selected elements was performed using inductively coupled plasma-optical emission spectrometry (ICP-OES) (Varian Vista-MPX). The concentration of the studied elements was reported as $\mathrm{mg} / \mathrm{kg}$. The accuracy of analysis was examined by analysing in duplicate the NIST-1547 Sigma-Aldrich standard research material (SRM) of peach leaves.

\section{Method validation}

\section{Results and Discussion}

The result of recovery analysis of the selected elements was compatible with the certified values of peach leaves (NIST-1547). The recovery percentage of the measured elements was found to be acceptable, ranging between 66.3 and $105.24 \%$ (Table 2). Only Ca showed the value lower than $70 \%$.

Table 2. The value of accuracy of analysis for standard reference

\begin{tabular}{lccc}
\hline Elements & $\begin{array}{c}\text { Analysed Value } \\
(\mathbf{m g} / \mathbf{k g})\end{array}$ & $\begin{array}{c}\text { Certified Value } \\
(\mathbf{m g} / \mathbf{k g})\end{array}$ & $\begin{array}{c}\text { Recovery } \\
(\mathbf{\%})\end{array}$ \\
\hline $\mathrm{Ca}$ & 10334.81 & 15590 & 66.3 \\
$\mathrm{~K}$ & 21188.53 & 24330 & 87.1 \\
$\mathrm{Mg}$ & 3671.85 & 4320 & 85.0 \\
$\mathrm{Al}$ & 241.84 & 248 & 97.5 \\
$\mathrm{Fe}$ & 227.09 & 219.8 & 103.3 \\
$\mathrm{Mn}$ & 89.02 & 97.8 & 91.0 \\
$\mathrm{Cu}$ & 3.85 & 3.75 & 102.7 \\
$\mathrm{Cd}$ & 0.03 & 0.0261 & 105.2 \\
\hline
\end{tabular}

\section{Concentration levels of macroelements}

The mean value of each element is as follows: $\mathrm{Ca}>\mathrm{Na}>\mathrm{K}>\mathrm{Mg}>\mathrm{Mn}>\mathrm{Al}>\mathrm{Fe}>\mathrm{Zn}>\mathrm{Cu}>\mathrm{Pb}>\mathrm{Cd}$. In general, the concentration of all macroelements shows a decreasing trend from barks to leaves. The concentration levels of macroelements ranged from 593.67 to $2973.28 \mathrm{mg} / \mathrm{kg}$ for Ca, 421.80 to $1525.04 \mathrm{mg} / \mathrm{kg}$ for Na, 958.56 to 2344.82 $\mathrm{mg} / \mathrm{kg}$ for K, and 282.20 to $1163.32 \mathrm{mg} / \mathrm{kg}$ for $\mathrm{Mg}$ (Figure 1). Stem disks and leaves have low concentration of macroelements compared to other parts. Plants absorb nutrient through their roots or even via their stems and leaves, and accumulate them in their tissues; furthermore, plants take up elements selectively, which subsequently move through the biogeochemical cycle [12].

The high concentration of macroelements in $R$. apiculata is due to the high concentration of those elements in salt water. $R$. apiculata is a mangrove species that can adapt in saline environment. The salt tolerance of this plant can be defined as its capacity to endure the effects of salt excess in the medium of root growth [13]. This mangrove species may have the absorption mechanism [14], thus exhibits some restricted mobility via an obvious barrier to acropetal translocation process [15]. Halophytic plants like $R$. apiculata have special adaptation to grow in the area of high salt content [16]. Previous reports stated that every plant needs calcium for the growing process. This macroelement plays a very important role in the growth of a plant and cell wall deposition [17]. Thus, this explains the relatively high concentration of $\mathrm{Ca}$ in all parts of $R$. apiculata. 
Potassium is the mineral required in huge amounts by plants for metabolic functions and growth [18]. Leigh and Jones [19] reported that potassium is required for maintaining the intracellular electric neutrality, osmotic regulation, enzyme activation, protein synthesis, and photosynthetic metabolism. In saline environment, potassium becomes a vital element for osmotic regulation [20] and facilitates water uptake against strong external salt gradient [21]. Thus, this is an advantage for $R$. apiculata to adsorb some abundant elements in saline environment. In comparison to other elements, $\mathrm{Mg}$ has the lowest micronutrient concentration in all parts of $R$. apiculata.

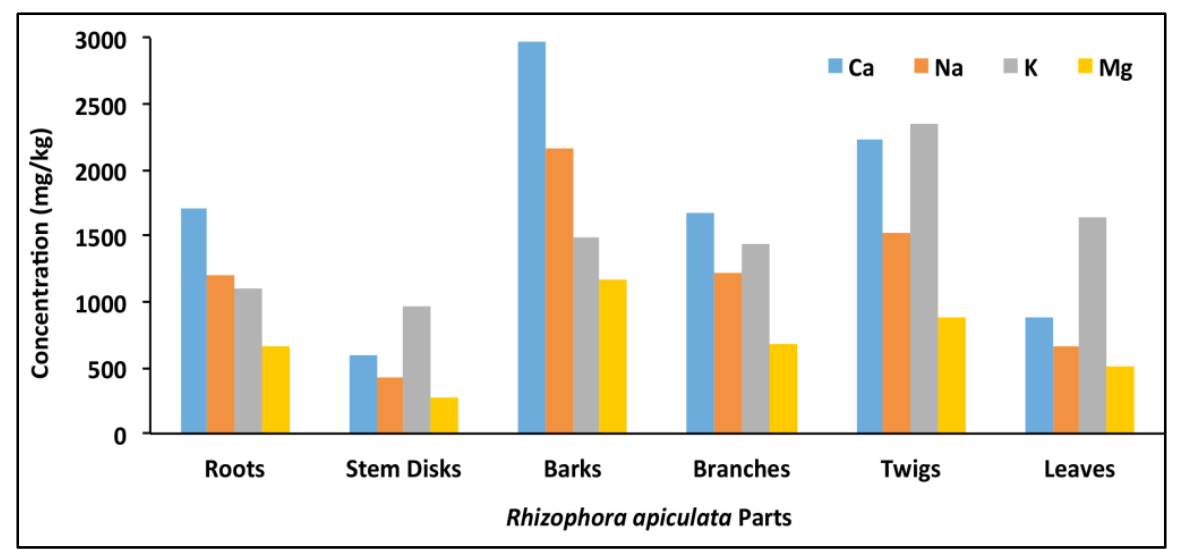

Figure 1. The concentration of macroelements in different parts of Rhizophora apiculata

\section{Concentration levels of microelements}

The concentration of microelements in the different parts of $R$. apiculata ranged from 59.99 to $235.09 \mathrm{mg} / \mathrm{kg}$ for $\mathrm{Mn}, 7.44$ to $76.32 \mathrm{mg} / \mathrm{kg}$ for Al, 9.23 to $48.46 \mathrm{mg} / \mathrm{kg}$ for Fe, 1.14 to $3.60 \mathrm{mg} / \mathrm{kg}$ for $\mathrm{Zn}$, and 0.53 to $1.40 \mathrm{mg} / \mathrm{kg}$ for $\mathrm{Cu}$. From the results, Mn tends to be higher compared to another microelements. This indicates that $\mathrm{Mn}$ is the essential microelement for plant growth and involves in the reduction of nitrates in green plants [22]. There are reasons for high concentration of $\mathrm{Mn}$ at different parts. In Figure 2, Fe is high in roots because it is needed for the growth of $R$. apiculata. The importance of $\mathrm{Fe}$ is well known in the formation of chlorophyll, protein synthesis, and root growth [23]. Thus, high accumulation of $\mathrm{Fe}$ in roots indicates the importance of this element in the root cell formation. Another reason of high $\mathrm{Mn}$ and Fe concentrations in each part of $R$. apiculata is due to the oxygen released by the mangrove roots that creates geochemical oxidant [8]. Both elements in the form of $\mathrm{Fe}^{2+}$ and $\mathrm{Mn}^{2+}$ will be oxidized into the insoluble forms of $\mathrm{Fe}(\mathrm{OH})_{3}$ and $\mathrm{MnO}_{2}$ [24].






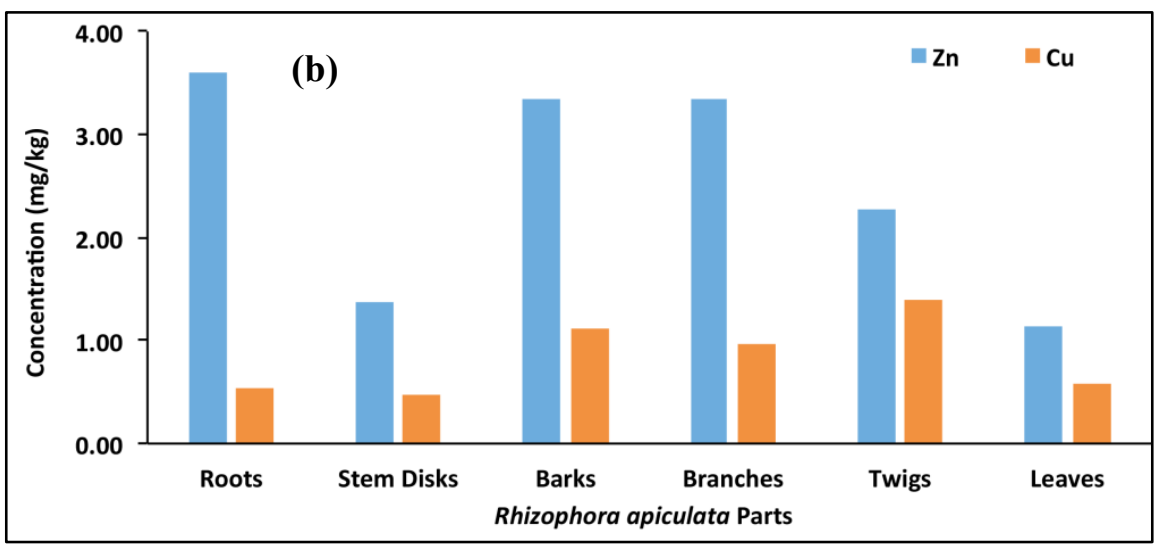

Figure 2. Concentration of microelements in different parts of Rhizophora apiculata

Figure $2 \mathrm{~b}$ shows that $\mathrm{Zn}$ and $\mathrm{Cu}$ are present in the studied parts. The presence of both elements in plants is necessary for chloroplast reactions, enzyme systems, protein synthesis, and metabolism [25]. According to Anikwe et al. [26], mangrove trees are known with the capability to accumulate a considerable number of elements in roots and barks. However, the concentrations of microelements in each part of $R$. apiculata tend to be different due to the translocation and distribution process of the absorbed elements to other parts. Each element has different concentration in each component. This suggests that the element is immobilized and some elements are transported to the upper parts of the plant [27].

\section{Concentration levels of non-essential elements}

Concentrations of non-essential elements were recorded at the low range from 0.01 to $0.03 \mathrm{mg} / \mathrm{kg}$ for $\mathrm{Cd}$ and 0.08 to $0.35 \mathrm{mg} / \mathrm{kg}$ for $\mathrm{Pb}$ (Figure 3). The abundance of $\mathrm{Cd}$ may reflect from the natural background of the environment. The accumulation of $\mathrm{Pb}$ in $R$. apiculata in this research was at a normal range concentration $(5.0-10.0 \mathrm{mg} / \mathrm{kg}) \mathrm{in}$ plant material [28, 29]. Usman et al. [30] suggested that low concentration of $\mathrm{Pb}$ is due to the reaction with phosphates, hydroxides, carbonates, clays, and organic matters, which resulted in low solubility of $\mathrm{Pb}$. This shows that $\mathrm{Pb}$ is immobile; besides, it has low solubility in low $\mathrm{pH}$ environment.



Figure 3. Concentration of non-essential elements in different parts of Rhizophora apiculata

\section{Principal component analysis}

The source of metal uptake was identified using principal component analysis through eigen-decomposition method. Principal components show pronounced change in the scree plot after 2 eigenvalues $(6.72,2.67)$. In this study, two 
principal components rendered explained about $85.70 \%$ of the total variance in the data sets as illustrated in Figure 4. It is clearly shown that the metal uptake by R. apiculata tends to be dominant for barks. Both essential elements, $\mathrm{Al}$ and $\mathrm{Fe}$, were higher in the roots of $R$. apiculata, thus giving an idea that negative impact is minimal since it is useful for plant growth. Despite the concentrations on non-essential elements ( $\mathrm{Pb}$ and $\mathrm{Cd})$ are still low, it is noteworthy to highlight that there is a potential of metal accumulation as similar observation was also recorded for the same species by Kamaruzzaman et al. with higher concentration [10].

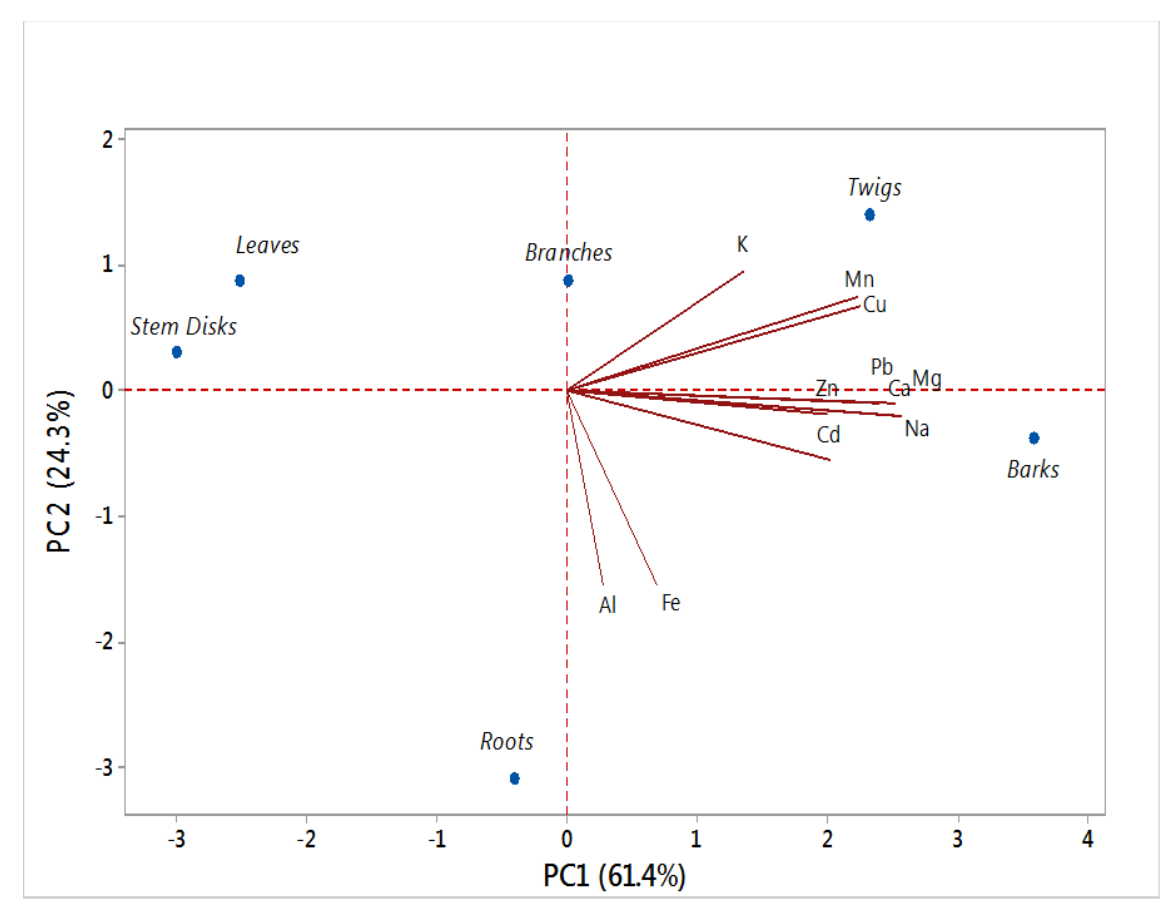

Figure 4. Biplot of principle component analysis

The concentration of elements in the present study was compared with the studies conducted in China [31, 32] and India $[24,33]$ (Table 3). Previous reports were based on the selected elements and did not divide them into different categories. Comparatively, the concentrations of micro and non-essential elements in the studied parts were lower than the other studies, except for Fe and Mn. The concentration of Mn was relatively higher than the values reported by Kathiresan et al. [24] in Cuddalore, India. The concentrations of $\mathrm{Pb}$ and $\mathrm{Cd}$ can be classified as low compared to other studies. It can be concluded that the concentration of the studied elements is low and Kuala Sepetang mangrove area is receiving the studied elements from the natural sources.

Table 3. A comparison of micro- and non-essential element in the different parts of mangrove species

\begin{tabular}{lccccccc}
\hline \multirow{2}{*}{ Species } & \multirow{2}{*}{ Ref. } & \multicolumn{5}{c}{ Concentration (mg/kg) } \\
\cline { 3 - 8 } & & Roots & Stem Disk & Bark & Branches & Twig & Leaves \\
\hline Iron & & & & & & \\
R. apiculata & This study & $48.48 \pm 12.25$ & $3.21 \pm 1.65$ & $23.16 \pm 3.96$ & $13.27 \pm 5.13$ & $13.79 \pm 3.15$ & $9.23 \pm 2.50$ \\
A. marina & {$[24]$} & $1087.0 \pm 2.8$ & $31.0 \pm 2.8$ & $125.0 \pm 2.7$ & n.a. & n.a. & $131.0 \pm 2.9$ \\
A. corniculatum & {$[32]$} & 4619 & n.a. & n.a. & n.a. & 0.91 & 3.23 \\
\hline Copper & & & & & & \\
R. apiculata & This study & $0.53 \pm 0.13$ & $0.21 \pm 0.12$ & $1.11 \pm 0.36$ & $0.97 \pm 0.60$ & $1.40 \pm 0.96$ & $0.58 \pm 0.15$ \\
A. marina & {$[24]$} & $58.00 \pm 0.70$ & $41.00 \pm 0.70$ & $61.00 \pm 0.70$ & n.a. & n.a. & $12.00 \pm 0.70$ \\
& {$[31]$} & $30 \pm 2$ & n.a. & n.a. & n.a. & $16 \pm 2$ & $12 \pm 1$ \\
A. corniculatum & {$[32]$} & 57.3 & n.a. & n.a. & n.a. & 6.71 & 5.28 \\
\hline
\end{tabular}


Table 3 (cont'd). A comparison of micro- and non-essential element in the different parts of mangrove species

\begin{tabular}{|c|c|c|c|c|c|c|c|}
\hline \multirow{2}{*}{ Species } & \multirow{2}{*}{ Ref. } & \multicolumn{6}{|c|}{ Concentration (mg/kg) } \\
\hline & & Roots & Stem Disk & Bark & Branches & Twig & Leaves \\
\hline \multicolumn{8}{|l|}{ Manganese } \\
\hline R. apiculata & This study & $59.99 \pm 6.26$ & $18.04 \pm 24.6$ & $235.09 \pm 40.38$ & $169.19 \pm 24.87$ & $207.45 \pm 53.64$ & $65.07 \pm 9.16$ \\
\hline A. marina & {$[24]$} & $21.00 \pm 0.30$ & $11.00 \pm 0.4$ & $28.00 \pm 0.10$ & n.a. & n.a. & $5.00 \pm 0.30$ \\
\hline A. corniculatum & {$[32]$} & 740 & n.a. & n.a. & n.a. & 135 & 466 \\
\hline \multicolumn{8}{|l|}{ Zinc } \\
\hline R. apiculata & This study & $3.60 \pm 0.97$ & $1.38 \pm 0.54$ & $3.35 \pm 1.22$ & $3.35 \pm 2.50$ & $2.27 \pm 0.35$ & $1.14 \pm 0.34$ \\
\hline \multirow[t]{2}{*}{ A. marina } & [24] & $21.0 \pm 0.8$ & $12.00 \pm 0.2$ & $17.0 \pm 0.9$ & n.a. & n.a. & $9.0 \pm 0.4$ \\
\hline & {$[31]$} & $37 \pm 5$ & n.a. & n.a. & n.a. & $15 \pm 1$ & $17 \pm 1$ \\
\hline A. corniculatum & {$[32]$} & 82.8 & n.a. & n.a. & n.a. & 11 & 23.4 \\
\hline \multicolumn{8}{|l|}{ Cadmium } \\
\hline R. apiculata & This study & $0.02 \pm 0.01$ & $0.01 \pm 0.01$ & $0.03 \pm 0.01$ & $0.01 \pm 0.001$ & $0.02 \pm 0.01$ & $0.01 \pm 0.006$ \\
\hline \multirow[t]{3}{*}{ A. marina } & {$[24]$} & $0.60 \pm 0.12$ & $0.00 \pm 0.00$ & $0.40 \pm 0.10$ & n.a. & n.a. & $0.10 \pm 0.01$ \\
\hline & {$[31]$} & $0.15 \pm 0.01$ & n.a. & n.a. & n.a. & $0.10 \pm 0.02$ & $0.09 \pm 0.1$ \\
\hline & {$[33]$} & 4.05 & 1.83 & n.a. & n.a. & n.a. & 5.71 \\
\hline \multicolumn{8}{|l|}{ Lead } \\
\hline \multirow[t]{2}{*}{ R. apiculata } & This study & $0.22 \pm 0.13$ & $0.11 \pm 0.06$ & $0.31 \pm 0.13$ & $0.16 \pm 0.05$ & $0.35 \pm 0.11$ & $0.08 \pm 0.04$ \\
\hline & {$[9]$} & 2.05 & n.a. & 1.05 & n.a. & n.a. & 1.43 \\
\hline \multirow[t]{3}{*}{ A. marina } & {$[24]$} & $7.0 \pm 0.4$ & $6.0 \pm 0.3$ & $16.0 \pm 0.4$ & n.a. & n.a. & $6.0 \pm 0.4$ \\
\hline & {$[31]$} & $4.4 \pm 0.4$ & n.a. & n.a. & n.a. & $1.0 \pm 0.3$ & $0.9 \pm 0.1$ \\
\hline & [33] & 1.57 & 0.38 & n.a. & n.a. & n.a. & 0.84 \\
\hline A. corniculatum & {$[32]$} & 18.2 & n.a. & n.a. & n.a. & 0.91 & 3.23 \\
\hline
\end{tabular}

* n.a. - not available

\section{Conclusion}

This study provides a baseline data of macroelements, microelements, and non-essential elements in different parts of 20-year-old R. apiculata at Kuala Sepetang Mangrove Reserve Forest. The average concentration of the studied elements is as follows: $\mathrm{Ca}>\mathrm{Na}>\mathrm{K}>\mathrm{Mg}>\mathrm{Mn}>\mathrm{Al}>\mathrm{Fe}>\mathrm{Zn}>\mathrm{Cu}>\mathrm{Pb}>\mathrm{Cd}$. Macroelements were recorded high in all samples due to their abundance in salt water and are important for the mangrove tree growth in saline environment. Microelements may be supportive elements for plant growth and the concentration might not be as high as macronutrient elements. The low concentrations of $\mathrm{Pb}$ and $\mathrm{Cd}$ suggest that the study area is not strictly affected by the anthropogenic sources of non-essential elements. This study provides useful baseline data for the Perak Forestry Department and the charcoal industry in Kuala Sepetang, Perak, Malaysia.

\section{Acknowledgements}

This work was funded by the Research Acculturation Grant Scheme (RAGS) vot no. 57097 from Universiti Malaysia Terengganu (UMT). The authors would like to appreciate the Forestry Department of Malaysia especially Larut Matang District Forest Office for their cooperation and permission to collect samples from Kuala Sepetang Mangrove Reserve Forest. The authors acknowledge the School of Marine and Environmental Sciences, and Institute of Oceanography and Environment (INOS) for providing facilities to carry out this research.

\section{References}

1. Mazlan, A. G., Zaidi, C. C., Wan-Lotfi, W. M. and Othman, B. H. R. (2005). On the current status of marine bio-diversity in Malaysia. Indian Journal of Marine Science, 34: 76-87.

2. Agoramoorty, G., Chen, F. A. and Hsu, M. J. (2008). Threat of heavy metal pollution in halophytic and mangrove plants of Tamil Nadu, India. Journal of Environmental Pollution, 155: 320-326. 
Fathullah et al: MACRO, MICRO, AND NON-ESSENTIAL ELEMENTS IN DIFFERENT PARTS OF Rhizophora apiculata

3. Lewis, M., Pryor, R. and Wilking, L. (2011). Fate and effects of anthropogenic chemical in mangrove ecosystem: A review. Journal of Environmental Pollution, 159: 2328-2346.

4. Sternberg, L. D. L., Teh, S. Y., Ewe, S. M. L., Miralles- Wilhelm, F. and DeAngelis, D. 1. (2007). Competition between hardwood hammocks and mangrove. Journal of Ecosystem, 10: 648-660.

5. Kathiresan, K. and Qasim, S. Z. (2005). Biodiversity of mangrove ecosystem. New Delhi, India: Hindustan Publishing Corporation (India), New Delhi: pp. 251.

6. Rönnbäck, P., Troell, M., Kautsky, N. and Primavera, J. H. (1999). Distribution pattern of shrimps and fish among Avicennia and Rhizophora microhabitats in the Pagbilao mangrove, Philippines. Journal of Estuarine, Coastal and Shelf Science, 48: 223-234.

7. MacFarlane G. R. and Burchett M. D. (2002). Toxicity, growth and accumulation relationships of copper, lead and zinc in the grey mangrove Avicennia marina (Forsk.) Vierh. Marine Environmental Research, 54: 65-84.

8. Silva, C. A. R., Lacerda, L. D. and Rezende, C. E. (1990). Heavy metal reservoirs in a red mangrove forest. Journal of Biotropica, 22: 339-345.

9. Kamaruzzaman, B. Y. and Ong, M. C. (2009). Accumulation of lead and copper in Rhizophora apiculata from Setiu mangrove forest, Terengganu, Malaysia. Journal of Environmental Biology, 30: 821-824.

10. Kamaruzzaman, B. Y., Rina Sharlinda, M. Z., John, B. A. and Waznah, A. S. (2011). Accumulation and Distribution of lead and copper in Avicennia marina and Rhizophora apiculata from Balok mangrove forest, Pahang, Malaysia. Sains Malaysiana, 40(6): 555-560.

11. Wu, S., Feng, X. and Wittmeier, A. (1997). Microwave digestion of plant grain reference materials in nitric acid or mixture of nitric acid and hydrogen peroxide for the determination of multi-elements by inductively coupled plasma mass spectrometry. Journal of Analytical Atomic Spectrometry, 12: 797-806.

12. Ramos, S. C. A., da Silva, A. P. and de Oliveira. S. R. (2006). Concentration, stock and transport rate of heavy metals in a tropical red mangrove, Natal, Brazil. Marine Chemistry, 99: 2-11.

13. Teiz, L. and Zeiger, R. (1991). Plant physicology. The Benjamin-Cumming Publishing Company, Redwood City, CA, USA: pp. 565.

14. Qiu, Y. W., Yu, K. F., Zhang, G. and Wang, W. X. (2011). Accumulation and partitioning of seven trace elements in mangroves and sediment cores from three estuarine wetlands of Hanan Island, China. Journal of Hazardous Materials, 190: 631-638.

15. MacFarlane, G. R., Pulkownik, A. and Burchett M. D. (2003). Accumulation and distribution of heavy metals in the grey mangrove, Avicennia marina (Forsk.) Vierh: Biological indication potential. Environmental Pollution, 123: 139-151.

16. Glenn, E. P., Brown, J. J. and Blumwald, E. (1999). Salt tolerance and crop potential of halophytes. Journal of Critical Review of Plant Sciences, 18: 227-255.

17. Khalil, N. A., Al-Murshidy, W. A., Eman, A. M. and Badawy, R. A. (2015). Effect of plant density and calcium nutrition on growth and yield of some faba bean varieties under saline condition. Journal of International Scientific Publications, 3: 440-450.

18. Hsiao, T. C. and Lauchli, A. (1986). Role of potassium in plant-water relation. Advanced Plant Nutrition, 2: 2831.

19. Leigh, R. A. and Wyn Jones, R. G. (1984). A hypothesis relating critical potassium concentrations for growth to the distribution and functions of this ion in the plant cell. New Phytologist, 97: 1-13.

20. Downton, W. J. S. (1982). Growth and osmotic relations of the mangrove Avicennia marina, as influenced by salinity. Functional Plant Biology, 9(5): 519-528.

21. Reef, R., Feller, I. C. and Lovelock, C. E. (2010). Nutrition of mangroves. Tree Physiology, 30(9): 1148-1160.

22. Chowdhury, R., Favas, P. J C., Pratas, J., Jonathan, M. P., Ganesh, P. S. and Sarkar, S. K. (2015). Accumulation of trace element by mangrove plants in Indian Sundarban Wetland: Prospects for phytoremediation. International Journal of Phytoremediation, 17(9): 885-894.

23. Jones, J. B., Wolf, B. and Mills, H. A. (1991). Plant analysis handbook: A practical sampling, preparation, analysis and interpretation guide. Micro and Macro Publishing, New York.

24. Kathiresan, K., Saravanankumar, K. and Mullai, P. (2014). Bioaccumulation of trace elements by Avicennia marina. Journal of Coastal Life Medicine, 2(11): 888-894.

25. Shaw, A. J. (1990). Heavy metal tolerance in plant: Evolutionary Aspects. CRC Press, Florida. 
26. Anikwe, M. N. and Nwobodo, K. C. A. (2002). Long-term effect of municipal waste disposal on soil properties and productivity of sites used for urban agriculture in Abakaliki, Nigeria. Bioresources Technology, 83: 241250 .

27. Abohassan, R. A. (2013). Heavy metal pollution in Avicennia marina mangrove system on the Red Sea Coast of Saudi Arabia. Journal of King Abdulaziz University; Meteorology, Environment and Arid Land Agriculture Science, 24: 35-53.

28. Alloway, B. J. (1995) Soil processes and the behaviour of metals. In: Alloway BJ (ed). Heavy metals in soils. Blackie Academic and Professional, New York: pp. 11-50.

29. Bodin, N., Gom-Kâ, R., Thiaw, O. T., Tito de Morais, L., Le Loc'h, F. and Rozuel-Chartier, E. (2013). Assessment of trace metal contamination in mangrove ecosystem from Senegal, West Africa. Chemosphere, 90: 50-57.

30. Usman, A. R. A., Alkredaa, R. S. and Wabel, M. I. A. (2013). Heavy metal contamination in sediments and mangroves from the coast of Red Sea: Avicennia marina as potential metal bioaccumulator. Ecotoxicology and Environmental Safety, 97: 263-270.

31. Wang, Y., Qiu, Q., Xin, G., Yang, Z., Zheng J., Ye, Z. and Li, S. (2013). Heavy metal contamination in a vulnerable mangrove swamp in South China. Environmental Monitoring Assessment, 185(7): 5775-5787.

32. Yu, R. L., Hu, G. R., Zhang, W. F. and Liu B. X. (2015). Accumulation and transfer of heavy metals in the mangroves from Quanzhou Bay Wetland, South East Coast of China. Journal of Residuals Science \& Technology, 12: 79-83.

33. Nirmal Kumar, I. J., Sajish, P. R., Nirmal Kumar, R., Basil, G. and Shailendra, V. (2011). An assessment of the accumulation potential of $\mathrm{Pb}, \mathrm{Zn}$ and $\mathrm{Cd}$ by Avicennia marina (Forssk.) Vierh. in Vamleshwar Mangroves, Gujarat, India. Notulae Scientia Biologicae, 3(1): 36-40. 